\title{
Promoting partnership Campus and community collaboration through cultural events
}

l: is 11:30 a.m. on Saturday, and the library

is hopping. Dozens of people pack into a small lecture room and listen intently as a faculty members son and daughter give a card-theater performance of Momotaro: The Peach Boy.

In the nearby seminar room, a lively group crowds around a table to learn how to make cucumber sushi rolls. The hallway bustles with students and community members waiting to try their hand at calligraphy or try on a yukata. Picture books of Japanese folk tales in English and Japanese compete for attention with Japanese architecture books, graphic novels, and maps.

Clearly, it s not your ordinary weekend morning at an academic library. On November 18, 2006, Miami University (Ohio) Libraries hosted a Japanese cultural festival and read-in called Ohanashi: Discovering Japan Through Stories. ${ }^{1}$ Sponsored by a grant from the Japan Foundation s Center for Global Partnership, the program sought to promote Japanese cultural education, while fostering ties between the library and campus and community organizations.

Ohanashi was a four-hour event that attracted more than 600 participants from the campus and community, with some visitors coming from more than an hour away. Librarians partnered with faculty, staff, and students from a number of departments and organizations including Education, Asian Studies, service learning, sororities and fraternities, and student service clubs. Community participants included local K 12 students and teachers, scout troops, homeschool groups, and public librarians and patrons.

\section{Why host cultural events?}

While hosting such an event presents the challenges of time, staffing, and budget (even grant funding typically requires some matching or in-kind funds), the bene ts for both the university and community are worth the effort. Here are six good reasons why academic libraries should consider opening their doors, resources, and expertise to the community.

1. Faculty and staff partnerships. Ohanashi fostered cooperation between librarians and faculty and staff. Individuals participated in a number of different ways, including the following: creating posters of aspects of Japanese culture, loaning cultural items from their personal collections, promoting the event by sending e-mails through electronic lists, volunteering during the event, presenting a story for the read-in, or simply by attending with their families and friends. Networking led us to involvement with many enthusiastic and knowledgeable persons with interest in Japanese culture, which created potential for future projects.

2. Partnerships with administrative units and organizations on campus. Many campuses have of ces devoted to promoting diversity. At Miami University, we had assistance from the Center for American and World Cultures and the Partnership of ce, an administrative unit that promotes partnerships between

Stacy Brinkman is art architecture librarian and assistant librarian, e-mail: brinkmsn@muohio.edu, and Frances Weinstein Yates is instruction materials librarian/ assistant librarian, e-mail:yatesf@muohio.edu, at Miami University (Ohio)

(c) 2008 Stacy Brinkman and Frances Weinstein Yates 
the university and local K 12 school districts. Other ofces that provided promotional support and student contacts included Admissions, Student Affairs, Department of Teacher Education, and the Of-

ce of International Education.

3. Connections with students. Stu-

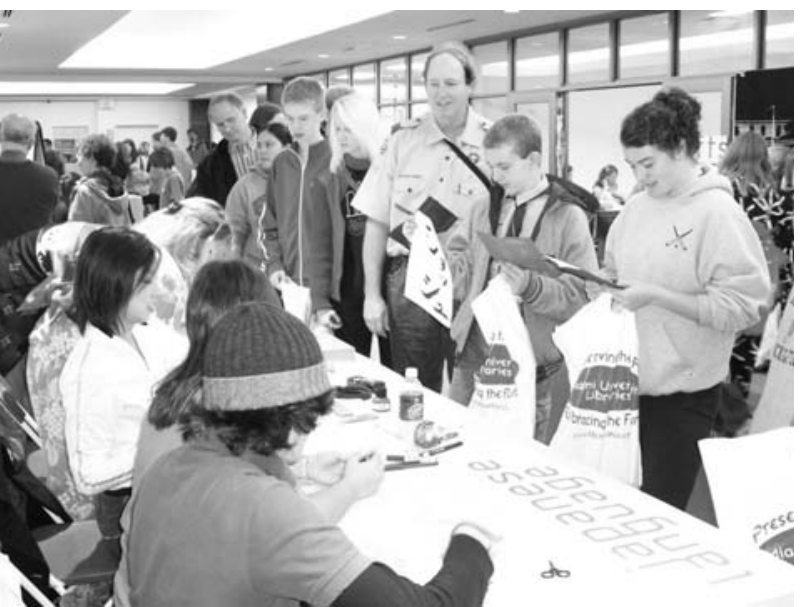

Ohanashi participants of varying ages have their names written in Japanese calligraphy.

part of their exploration of speci c cultures. Our school contacts ranged from going into art classes to do origami workshops to visiting an eighth-grade language arts class to kick-off a curriculum unit on Japanese literature. Many additional options for com-

dents from various departments and campus organizations participated in Ohanashi by volunteering, presenting stories, providing supplies, event promoting, or attending. Student groups that were particularly supportive included members from the Japanese Language and Culture Club, students in the Teacher Education program, members of student service groups (like Circle $\mathrm{K}$ International and Alpha Phi Omega), students involved with Big Brother/Big Sister programs, and students who had studied abroad. Cultural or thematic programs like this are an excellent way to get the library connected with students extracurricular activities and interests, allowing them to take ownership of parts of the program to show off their knowledge and skills.

4. Outreach to the community. At the most basic level, getting 600 people into the library building was an excellent way to market the university and the library. With the cooperation of the Admissions of ce, we were able to distribute materials about Miami University at our information table, and participants of the program received information and promotional materials from the library, as well.

The planning of this event enabled us to make connections with local public libraries, many of which already had Japanese-themed programs, such as Yuh-gi-oh! and manga/anime groups. We also met with local scouting troops and K 12 teachers. Scouts offer badges for world culture activities, and several troop leaders were eager to have scouts attend as munity curriculum connections were possible but were unfortunately limited by lack of time and limited staf ng.

Extension programs in local K 12 schools demonstrate that programs like Ohanashi have the potential for a broad and long-lasting impact in the community. Reports from the coordinator of gifted education, who facilitates a local after-school language program for students in grades two through ve noted an increase in the selection of Japanese as the language choice. Of six language selections, Japanese had previously been ranked $\# 5$ and moved up to \#3 after the Ohanshi event. Thanks to Miami University foreign language students who connected with a neighboring school district through their participation in Ohanashi, Miami University was able to offer an after-school learning program that featured eight weeks of Japanese culture and language study for youth ages 9 to 12 . These kinds of programs show how the university library can take an active role in transforming a communitys awareness and appreciation of other cultures.

5. Commitment to diversity and multicultural awareness. Partnering with campus, community, and national organizations to bring cultural programs to the library not only actively promotes the cause of diversity, but also locates the library as a place that is committed to multicultural awareness and inclusiveness. For colleges located in areas that lack natural demographic diversity, the 
library can become a place of cultural encounter and discovery.

Miami University is located in Oxford, Ohio, a small college town in Southwest Ohio and bordering East Central Indiana, surrounded by rural counties. The university and nearby school districts are largely monocultural, with predominantly White populations ranging from 92 to 99 percent. One of the comments that we heard most often from participants and volunteers during Ohanashi was that it was so wonderful and important to have cultural events for the community, and that it was great that the library was hosting such a program.

6. Collection development. The Miami University Libraries received a direct bene $t$ from this program in the form of more than 150 new books appropriate for use in the K 12 curriculum. Housed in the Instructional Materials Center (IMC), a unit that serves pre-service and in-service teachers and noneducation majors involved in tutoring programs, the materials added to this collection included translated folk tales, picture books, easy readers, and kamishibai (Japanese stories in a traditional card theater format).

These books were put on display throughout Ohanashi, and participants were able to read them in a quiet library corner area. This collection has received extensive use and the IMC staff is currently preparing a resource activities guide to assist teachers in sharing this literature with students as part of thematic curriculum units.

\section{Other opportunities for cultural events and partnerships}

Ohanashi is just one example of the type of program academic libraries can provide to forge partnerships with faculty, staff, students, and communities, and to promote cultural awareness and understanding. The following list describes a few existing programs that librarians can use to start campus and community collaboration.

Japan Foundation Center for Global Partnership: Funding for Education
Projects in the South and Midwest, www. cgp.org. The Japan Foundation presents several awards of up to $\$ 5,000$ each year for projects that promote Japanese culture for K 12 students in specified regions. While the focus is not directly on college or university students, projects that involve higher education institutions are strongly encouraged to apply.

African-American Read-In, www. ncte.org/prog/readin. Now in its 18th year, the African-American Read-In is an excellent opportunity to partner with community groups and student organizations. Read-ins can be as simple or elaborate as you make them, and can also celebrate the literature of other cultures or groups: for example, Miami University Libraries hosted its rst Women s Read-In as part of a Herstory celebration of Women s History Month ${ }^{2}$ in March 2007.

ALA Public Programs of ce, www. ala.org/ala/ppo/publicprograms.htm and www.ala.org/ala/ppo/grantsandevents/ ndingoutabout.htm. The ALA Public Programs Of ce offers a variety of grants to fund interesting projects that bring campus and community together with exhibits, lecture series, book discussions, course-related activities, or other programs. Recent topics have included Lewis and Clark, Women in Medicine, and Benjamin Franklin. You can peruse the ALA Web site for practical tips on writing grants and subscribe to their moderated electronic list to be kept apprised of funding opportunities.

Let s Talk About It: Jewish Literature, www.ala.org/ala/ppo/grantsandevents /ppograntsevents.htm www.nextbook.org /ala/index.html. This discussion series is sponsored by the ALA Public Programs Ofce and Nextbook, an organization that promotes Jewish literature and culture. Grants of $\$ 2,500$ (for single-series) and $\$ 5,000$ (for two-series) are available to support training, materials, and honoraria for speakers. University and public library partner programs report attendance ranging from 15 to 50 participants at each book discussion session. 


\section{Other sources of grants for cultural programming}

National Endowment for the Humanities, www.neh.gov

National Endowment for the Arts, arts. endow.gov

National Assembly of State Arts Agencies

(NASAA), nasaa-arts.org

State Humanities Councils, www.neh. gov/whoweare/statecouncils.html

Institute of Museum and Library Services, www.imls.gov

Foundation Center: The RFP Bulletin lists numerous and diverse grants and a weekly e-newsletter, foundationcenter. org/newsletters/.

\section{Tips for success}

Hosting a program that involves both campus and community can present some challenges, especially in the areas of publicity and organization. Before embarking on such a project, it is useful to take inventory of the human resources you have in the following areas:

\section{Publicity/marketing}

Maximize personal contacts. The most effective source of publicity is often word-ofmouth through personal contacts.

Have a graphics and Web site designer on board. Eye-catching graphics and a program Web site go a long way towards marketing your program effectively.

Cross-promote through different media. Using yers, posters, sandwich boards, and table tents in addition to a Web presence, e-mail lists, local and campusaf liated radio, and university Web site calendars will make your program more visible to the public.

\section{Organization}

Set up an organization site on Blackboard or similar course management program. Blackboard offers an easy interface to upload documents, send group e-mails, and post announcements for participating volunteers and coordinators on campus. Because students (especially) use Black- board every day, updates are more likely to be seen.

Establish a coordinating committee to delegate tasks and distribute information. Having well-de ned responsibilities will save organizers time and energy.

Write instructions for each volunteer position for the day of the event. This will help in case there are last-minute substitutions.

Provide orientation sessions for volunteers. Schedule an informal session to walk your volunteers through the event layout and allow them to ask questions. You will nd that you may have missed something.

\section{Other tips}

Plan ahead! Allow 6 to 12 months to establish community and campus stakeholders for the event. Getting a faculty member or K 12 teacher to require his or her class to participate in the event is an excellent way to increase attendance, but it is dif cult to get this level of support unless the faculty members have time to integrate the program theme into their course curriculum.

Send certi cates and thank-you cards to participants and volunteers. Your volunteers are valuable to the success of your program. Make them feel very appreciated.

Continue to promote information resources from your program (Web site, book collection) so that they continue to bene $t$ the community.

\section{Conclusion}

Hosting community-inclusive cultural events demonstrate that the library is committed to diversity and to creating learning experiences for persons of all ages. They are a worthwhile way to get student and administrative organizations involved with the library, and foster communication and partnerships between the campus and the community.

\section{Notes}

1. Ohanashi: Discovering Japan Through Stores, www.lib.muohio.edu/ohanashi.

2. Women s History Month is sponsored by the National Women s History Project, www. nwhp.org/whm/history.php. $\boldsymbol{n}$ 